\title{
Pathways of SME internationalization: a bibliometric and systematic review
}

\author{
Marina Dabić • Jane Maley • Leo-Paul Dana • \\ Ivan Novak • Massimiliano M. Pellegrini • \\ Andrea Caputo
}

Accepted: 15 April 2019/Published online: 22 June 2019

(C) The Author(s) 2019

\begin{abstract}
Business is dynamic and rapidly changing. Global markets were previously the playing field of multinational corporations (MNCs), while small and medium enterprises (SMEs) were local; however, the removal of imposed barriers and recent technological advances in manufacturing, transportation, and communications have indorsed SMEs and international entrepreneurs (IEs) global access. SMEs and IEs are
\end{abstract}

M. Dabić $(\bowtie) \cdot$ I. Novak

Faculty of Economics and Business, University of Zagreb, J. F.

Kennedy Square 6, HR-10000 Zagreb, Croatia

e-mail: mdabic@efzg.hr

e-mail: marina.dabic@ntu.ac.uk

M. Dabić

Business School, Nottingham Trent University, Burton Street, Nottingham NG1 4BU, UK

J. Maley

Department of Management, Faculty of Business and Economics, Macquarie University, Sydney, Australia

\section{L.-P. Dana}

Groupe Sup de Co Montpellier Business School, 2300 Avenue des Moulins, 34185 Montpellier Cedex 4, Montpellier, France

M. M. Pellegrini

Faculty of Economics, Rome, University of Rome "Tor Vergata", Rome, Italy

e-mail: massimiliano.pellegrini@uniroma2.it

A. Caputo

Lincoln International Business School, University of Lincoln, Lincoln, UK

e-mail: acaputo@lincoln.ac.uk increasingly fueling economic growth and innovation, and these trends are presenting both opportunities and challenges to both MNCs and SMEs in the global arena. This review systematically examines comparative SME and IE research, analyzing (after fine-tuning) 762 articles published in leading journals from 1992 to September 2018. Our bibliometric and systematic review classifies SME and IE research findings into three echelons: (i) subjects, (ii) theories, and (iii) methods.

Keywords Internationalization · SMEs · International entrepreneurship $\cdot$ Bibliometric analysis

JEL classification $\mathrm{F} 60 \cdot \mathrm{L} 26$

\section{Introduction}

Estimates suggest that more than $95 \%$ of enterprises across the world are small and medium enterprises (SMEs), and these contribute up to $60 \%$ of employment and up to $40 \%$ of GDP (Bell 2015). Thus, SMEs represent the backbone of national economic systems, but it is relatively recent that SMEs and multinational corporations (MNCs) share the same competitive space; less than two decades ago, Etemad et al. were observing how "competition in international markets was traditionally the realm of large companies, with smaller businesses remaining local or regional (2001, p. 481)." Indeed, for several reasons, such statement no longer applies because the world has become more competitive and increasingly globalized, making it necessary for SMEs to look outside of their national borders to 
survive (Lee et al. 2012). Similarly, the rapid development of technology has made internationalization strategies more accessible to SMEs. Remote working, artificial intelligence, the IoT, mobile apps, and social media have contributed to providing SMEs with more agile tools for expansion and internationalization (e.g., (Caputo et al. 2016a; Lee et al. 2012)). Such technological advancements are allowing for more integrated supply chains and speedy contacts with suppliers, contractors, and partners (Mangematin et al. 2003) and at the same time are reducing physical distances, thus allowing for a better reachability of markets, users, and potential customers, which were never imaginable for often limited-endowed companies such as SMEs (Musteen et al. 2014).

Given all these changes impacting the internationalization capacity of SMEs, several questions arise. What is the current state of the knowledge about internationalization of SMEs and international entrepreneurship? How has the internationalization of SMEs been researched and what findings have been produced? What lessons can we learn from this body of knowledge? This article aims at answering those questions by offering a timely and necessary review of the literature on internationalization of SMEs through a bibliometric methodology, which offers a systematic and comprehensive picture of what we know.

This study provides theoretical, practical, and methodological contributions. First, opposite of Keupp and Gassmann (Keupp and Gassmann 2009) and Jones et al. (Jones et al. 2011) which focused on international entrepreneurship research, we contribute to both the internationalization literature and the entrepreneurship literature by bridging the two together and integrating their findings when studying internationalization of SMEs. Second, we bring order, clarity, and systematization on the subject of internationalization of SMEs by identifying three level of analysis. The subject level, which investigates the main studied topics so far, and is composed of (1) knowledge transfer, (2) human resource development, and (3) refocusing geographical attention. The theoretical level, which investigates the theoretical foundations of the review studies, identified six main theoretical streams: (1) Uppsala model, (2) born global literature, (3) network theory, (4) transaction cost theory (TCT), (5) entrepreneurial theory, and (6) resourcebased view (RBV). The method level investigates which methods have been deployed by previous scholars. Third, we deploy an innovative method for reviewing the literature, which improves rigor and allows for a big picture to be presented without neglecting attention to the details. We contribute to the theoretical advancement of the field by integrating our findings in a research agenda, a key aspect for future scholars to bring the study of internationalization of SME further. Having introduced the topic and its relevance, this study proceeds explaining the methods used both for the bibliometric and systematic literature reviews, and it keeps this separation also in presenting the results (bibliometric analysis and the systematic review). Finally, our discussion concludes the paper showing possible areas to be addressed further.

\section{Theoretical background}

The debate on SMEs, internationalization and globalization, can be traced back to more than 40 years ago (e.g., (Bilkey and Tesar 1977; Coviello and McAuley 1999; McDougall and Oviatt 1996)), and since then, it has received increased attention (e.g., (Bratkovic et al. 2009); Keupp and Gassman 2009; (Jones et al. 2011)). There are many sub-topics or subfields of studies in this field, ranging from international entrepreneurship (e.g., (Oviatt and McDougall 2005)) to entry modes (e.g., (Brouthers and Nakos 2004)), strategies or resources used to internationalize (e.g., (Lu and Beamish 2001)), and Welch and Luostarinen (Welch and Luostarinen 1988) an "innovation-related internationalization model"-related research. Despite evident similarities in the investigated phenomena, each of such areas has often used a heterogeneity of concepts and knowledge bases to develop their discussion (García-Lillo et al. 2017). Thus, this fragmentation may miss to stress interconnections and synergies that different subfields may bring to the general discussion, lacking a systematic and comprehensive analysis of the spectrum of the phenomenon of internationalization of SMEs. Scholars have tended to specialize on one single domain only, but the actual state of knowledge is sufficiently developed to require a more serious effort to integrate and cross-fertilize each domain (Coviello and Jones 2004). The literature can be initially scanned to find the main theoretical aspects which lead the actual debate and represent the foundation paradigms.

In terms of entry modes, the stage models introduced by the Uppsala school (Johanson and Vahlne 1977; Johanson and Vahlne 2009; Johanson and Wiedersheim-Paul 1975) argue that firms pursue internationalization in a slow and 
incremental fashion. In contrast, the models of rapid internationalization - including the literature on born global, born regional, and international new ventures (Cavusgil and Knight 2015; Madsen and Servais 1997; Oviatt and McDougall 1994; Oviatt and McDougall 2005; Rialp et al. 2005) - argue that many firms do not follow an incremental stage approach but rather start their international activities from an early stage of life. However, the interplay of globalization pressures, local market conditions, and technology advancements may force SMEs to adapt to abrupt shifts in the competitive arena and be less able to take a deliberate and stable decision (Dana 2001).

In terms of theoretical perspectives, the resourcebased view (RBV) perspective (Barney 1991; Wernerfelt 1984) is used to explain the internationalization of a SME (McDougall et al. 1994) by looking at resources and characteristics that SMEs may employ to grant them success in going abroad or global. As Young et al. noted, "explanations for the emergence and growth of international entrepreneurial firms largely focus on the resource-based view and the network perspective. While these approaches are useful, we suggest that IE would benefit significantly from a greater emphasis on its 'international nature'. Therefore, theories of international business should be employed in conjunction with other approaches ((Young et al. 2003), p. 31)." Yet also other authors (e.g., (Priem and Butler 2001)) are more cautious in fully espousing the RBV paradigm since they highlight how these assumptions need to be balanced by external factors. The network strategy approach becomes very useful to understand the bootstrapping capacity of entrepreneurs and SMEs in terms of strategic alliances and joint ventures ((Dabic and Bach 2008); Ratten et al. 2007) and social capital as a vehicle for expansion and success (Musteen et al. 2014). Finally, transaction cost theory has also been used to explain why SMEs engage in internationalization (Ruzzier et al. 2006), where both antecedents and consequences of the decision of internationalization have been associated as a response to market failures (Brouthers and Nakos 2004). The relation between multinational enterprises (MNEs) and SMEs with the dilemma of cooperating or being absorbed is a central aspect under investigation by such studies (Mangematin et al. 2003). Even though other internationalization theories refer to the firm response to market failure, the unit of analysis is different. In transaction cost studies, the unit of analysis is the transaction itself and not the firm (Ruzzier et al. 2006). However, these assumptions have been frequently tested at an aggerated level (Coviello and Jones 2004), leaving less space for an interpretivist approach able to address cognitive reactions to the local market conditions.

If theoretically speaking these are the main subfields, another important angle for studying SMEs and their internationalization paths is related to the geographical location of the firms and contextual factors. There is a paucity of studies to take fully into account the antecedents and consequences of the embedded local or national conditions in which SMEs operate (Bloch and Bhattacharya 2016). For example, proximity, in terms of language, culture, and geographical distance, has often been regarded as positive related to the odds of success of an internationalization strategy adopted by SMEs (Caputo et al. 2016b). This is probably related to a concrete difficulty of SMEs, mostly due to resource constraints, to span into "distant" domains either in terms of markets, culture, legislations, etc. (Buckley and Ghauri 2004). For example, SMEs face legitimacy, economic, and resource dependence challenges in attracting and retailing talents that can help foster successful internationalization (Krishnan and Scullion 2017). Ribau et al. (Ribau et al. 2018) in recent study tried to map the field of internationalization of SMEs focused on the period between 1977 and 2014. Despite the growing interest in internationalization of SMEs and the relevant findings of this growing body of literature, the research is still fragmented and far from conclusive.

For all these reasons, we believe that this review is necessary to reconcile the various ways in which internationalization has been studied. We aim to contribute to the gap in the literature using a sequential mix method approach, based on a bibliometric analysis of the literature, followed by a systematic review, consistent with recent suggestions that the methodological rigor of literature reviews should be strengthened in management studies (e.g., (Denyer and Neely 2004; Thorpe et al. 2005; Tranfield et al. 2003)). More recent studies have also moved forward from the standard systematic literature review process in the search for more objectivity on article selection and categorization, resulting in the combination of bibliometric analysis of keywords and qualitative analysis of content (e.g., (Keupp et al. 2012; Saggese et al. 2016)). We agree with such approach as it brings the benefit of capturing a broader picture of the phenomenon (from the bibliometric analysis), showing structural dimensions of the knowledge bases used in the field and the individuation of similarities or schools 
(e.g., (García-Lillo et al. 2017)), with the benefit of the in-depth investigation of the findings and theoretical advancements of the reviewed studies (e.g., (Tranfield et al. 2003)).

\section{Method}

For the purpose of this paper, a mix of bibliometrics, content analysis, and systemic literature review tools has been used. Bibliometric analysis is based on the quantitative methods of multiple correspondences (Dabic et al. 2014; Dabic et al. 2015; Gonzalez-Loureiro et al. 2015; Gonzalez-Loureiro et al. 2017; López-Duarte et al. 2016) creating objective and useful information for scientists interested in the specific field while the literature review is based on the content analysis of selected papers (Duriau et al. 2007; Khoo et al. 2011; Seuring and Gold 2012). With respect to data coding, Short and Palmer (Short and Palmer 2008) categorize content analysis into three methods: "human-scored systems, individual word count systems, and computerized systems that use artificial intelligence." We combined computer-aided techniques, avoiding researcher bias and individual word count system in coding necessary for multiple correspondence analysis (MCA).

\subsection{Data collection}

To create an illustrative map of the scientific domain of internationalization of SMEs, a sample of papers was gathered through one of the most relevant scientific citation databases Web of Science Core Collection database, which included indexes such as SCI-EXPANDED, SSCI, A\&HCI, CPCI-S, CPCI-SSH, BKCI-S, BKCI-SSH, ESCI, CCR-EXPANDED, and IC. The first search was performed in June 2017, second in January 2018, and the final search was performed in September 2018.

The initial topic search string was composed of two parts: the first focuses on SMEs using: SME OR "small firm*" OR "small business*" OR "medium firm*" OR "medium business*" and the second focuses on identifying processes of internationalization, using globali?ation OR "born global" OR internationali?ation, where question marks were used as wildcards replacing any sign for the position. The total number of returned papers in all years from the query was 908. To isolate most relevant records (Castillo-Vergara et al. 2018), this first result was refined by excluding proceedings papers
(145), book chapters (38), editorial material (4), book reviews (3), news item (2), books (1), reprints (1), meeting abstracts (1), and corrections (1). The final number of records after the filtering process leaves only articles and reviews. After this step, a more detailed control of titles, keywords, and abstracts was performed independently by each author. After fine-tuning, 762 articles were analyzed.

\subsection{Data preparation}

After examining all the records obtained by the search, further process extracted a list of keywords combining two Web of Science Core Collection database categories: author's keywords and Keywords Plus. These keywords have been filtered for duplicates, and only unique values were used for cross-referencing the sample of gathered records. Following Hoffman and De Leeuw (Hoffman and de Leeuw 1992), a matrix was created by examining the presence of each unique keyword in every record. Each record included titles, abstracts, and keywords of selected papers and reviews. If the record did contain a keyword, the returned value was " 1 " and if not " $0 . "$ The first row of the matrix was about the keywords, the first column of the matrix was about the text of each record, and finally appropriate fields on their cross-section were about the binary values depending on the presence of the keyword in the text of each record. According to Gaur and Kumar (Gaur and Kumar 2018), content analysis involves "coding target textual data that is central to the qualitative data analysis (Drisko and Maschi 2016) and then subsequent summarization and analysis of the coded text."

\subsection{Software application}

By using the IBM SPSS Software we conducted a multiple correspondence analysis (MCA), as per Furrer and Sollberger (Furrer and Sollberger 2007) and Furrer et al. (Furrer et al. 2008). As explained by Benzécri (Benzécri 1982), Hoffman and Franke (Hoffman and Franke 1986), and Lebart et al. (Lebart et al. 1984), MCA is an exploratory data analysis technique for the graphical display of multivariate categorical data, allowing us to analyze interdependence among a set of categorical variables. This is similar to principal component analysis (Hoffman et al. 1994). MCA resulted in two dimensional coordinates of each keyword derived as a result of their mutual appearances in the selected 
records. Using the keywords' coordinates and their frequency of appearance, the first two-dimensional map of the selected research field was illustrated (axis $x$ : first coordinate; axis $y$ : second coordinate; size of the keyword's bubble: frequency of the records including the keyword). The map is demonstrating topic clustering and their importance in the selected field which is derived from the size of each keyword's bubble. Additional insights were accomplished by using previously calculated two-dimensional coordinates of each keyword and calculating their distance to the quantitative research marker (Gonzalez-Loureiro et al. 2015). The marker was designed by using relevant terms: quantitative, regression, correlate, panel analysis, panel data, statistics, numerical, econometrics, mathematics, minimax, vector measure, convexity, Lagrange, standard error, general equilibrium, heteroscedastic, game theory, optimization, dummy, least square linear, non*linear, geometric, rational choice theory, equation, and Bayesian. Distance was calculated on the basis of a Euclidian distance:

$d(d i, d j)=\sqrt{\left(x_{d i}-x_{d j}\right)^{2}+\left(y_{d i}-y_{d j}\right)^{2}}$

Using distance data (axis $x$ : distance to the marker, axis $y$ : frequency of the records including the keyword) enabled illustrating the second two-dimensional map of the selected research field. This provided an indication of the quantitative nature of research on internationalization of SMEs. The used protocol is summarized in Fig. 1.

\section{Bibliometric results}

First, we consider the consistency of the evolution of the field. Counting the number of papers published per year in the period of January 1992 to June 2017, the development of the field in question is quite visible (Fig. 2).

Among the influential journals are Journal of International Entrepreneruship (37), International Business Review (33), International Marketing Review (28), Journal of Small Business Management (20), International Small Business Journal (18), Small Business Economics (17), and Journal of World Business (17) (see Table 1).

Reflecting on the total number of citations, forerunner authors of the field are the following: Wright, M. (617), Westhead, P. (589), Ucbasaran, D. (588), Bell, J. (442), Fernandez, Z. (386), Nieto, MJ. (386), Lee, S.
(383), Igbaria (343), Iiviari (343), Antoncic (340), and Rruzzier (340) (all of them having more than 340 citations). Considering coauthorships, most influential authors tend to work together, e.g., Wrigth has a total of 5 papers published while four of them is coauthored with at least one of two other most influential authors: Westhead, P. and Ucbasaran, D. Titles of the most cited papers were the following: "The internationalization of new and small firms: A resource-based view" and "Internationalization of small and medium-sized enterprises (SMEs) and international entrepreneurship: A critique and policy implications and International market selection strategies selected by 'micro' and 'small' firms," published respectively in Journal of Business Venturing, Regional studies, and Omega-International Journal of Management Science. Furthermore, Bell, J. published a total of seven papers while four of them were coauthored with Loane, S. Other most influential authors were Park, G. (336), Park, J. (336), Yoon, B. (336), Pett, TL. (324), Wolff, JA. (324), Jones, M.V. (293), Hisrich, RD. (291), Loane, S. (287), and Crick, D. (272) (see Table 2).

To gain more insights into the journals' impact, the entire research period is divided into six periods (Table 3). The first period from 1992 to 2005was dominated by JSBM (Journal of Small Business Management), SBE (Small Business Economics), and JIM (Journal of International Marketing). The second period (2004-2009) was dominated by IMR (International Marketing Review), JSB (Journal of Small Business Management), and JSBED (Journal of Small Business and Enterprise Development). The third period (20102013) is dominated by ISBJ (International Small Business Journal), SBE (Small Business Economics), and ERD (Entrepreneurship and Regional Development). The fourth period (2010-2014) is dominated by JIE (Journal of International Economics) and ERD. The last periods (2015-2018) were the most productive encompassing $47.2 \%$ of all records for the selected journals with journals such as Journal of International Economics, International Business Review, International Marketing Review, and Journal of World Business.

For the purpose of mapping this research field, Fig. 3 is showing the two-dimensional map of the themes represented in the sampled records. Descriptors are derived from author's keywords and Keywords Plus given by the WOS database. Sets of these unique topics were compared against each record's title, abstract, and keywords creating a data matrix. Rows of this matrix are 


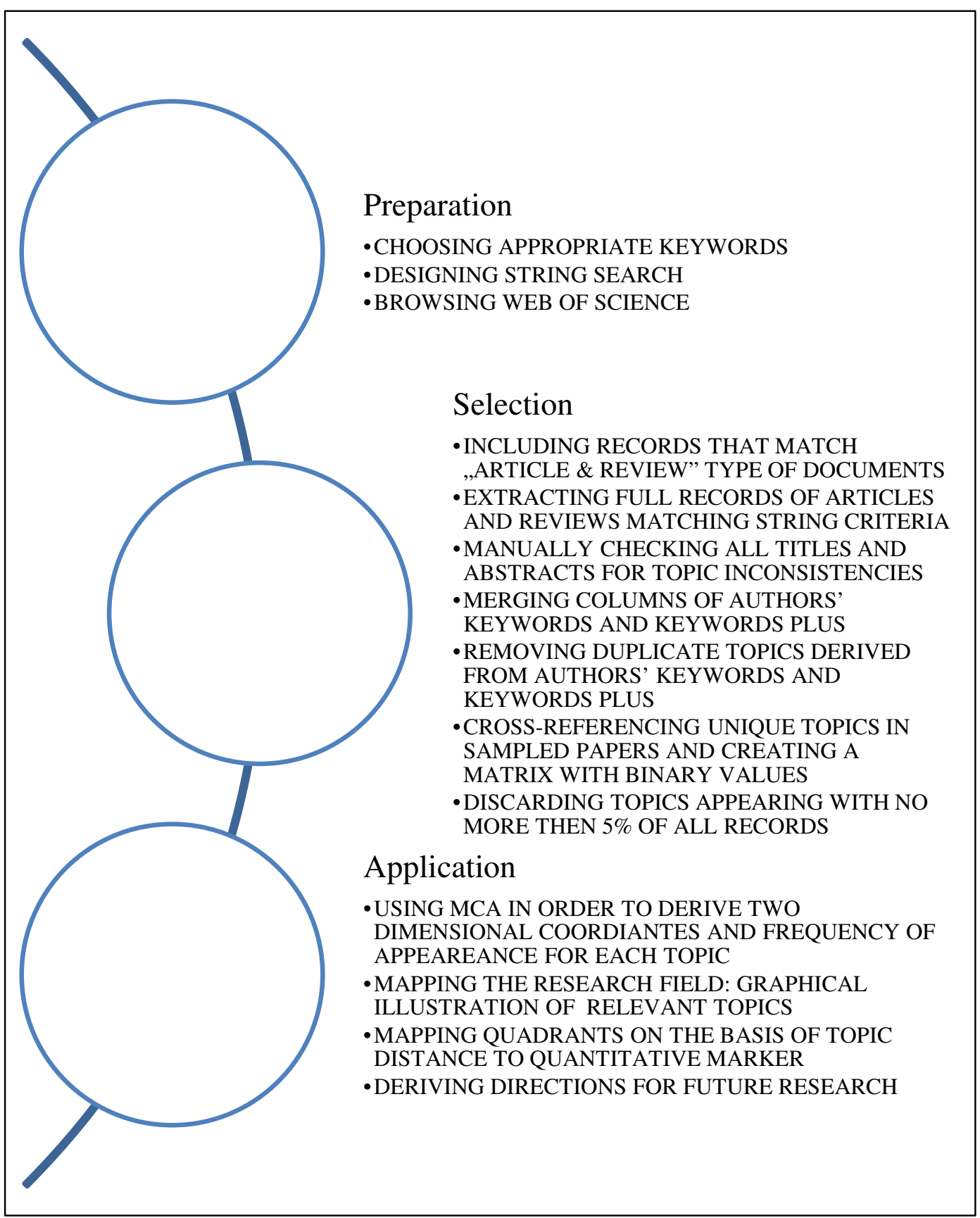

Fig. 1 Bibliometric protocol adopted

papers and columns are topics; the matrix is composed of zeroes and ones resulting from the crossing of the two dimensions: 1 if the topic is included in a certain record and 0 if the topic is not included. The matrix was filtered for most relevant topics, so those that are found in at least $5 \%$ of the papers were analyzed, and then it has been used to run a multiple correspondence analysis.
This analysis was performed by using HOMALS (homogeneity analysis by means of alternating least squares) command in SPSS. ${ }^{1}$ Such analysis yielded the two-dimensional coordinates of each keyword, where

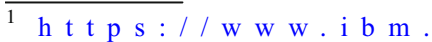

com/support/knowledgecenter/en/SSLVMB_24.0.0 /spss/categories/syn_homals_analysis.html\#syn_homals_analysis
} 


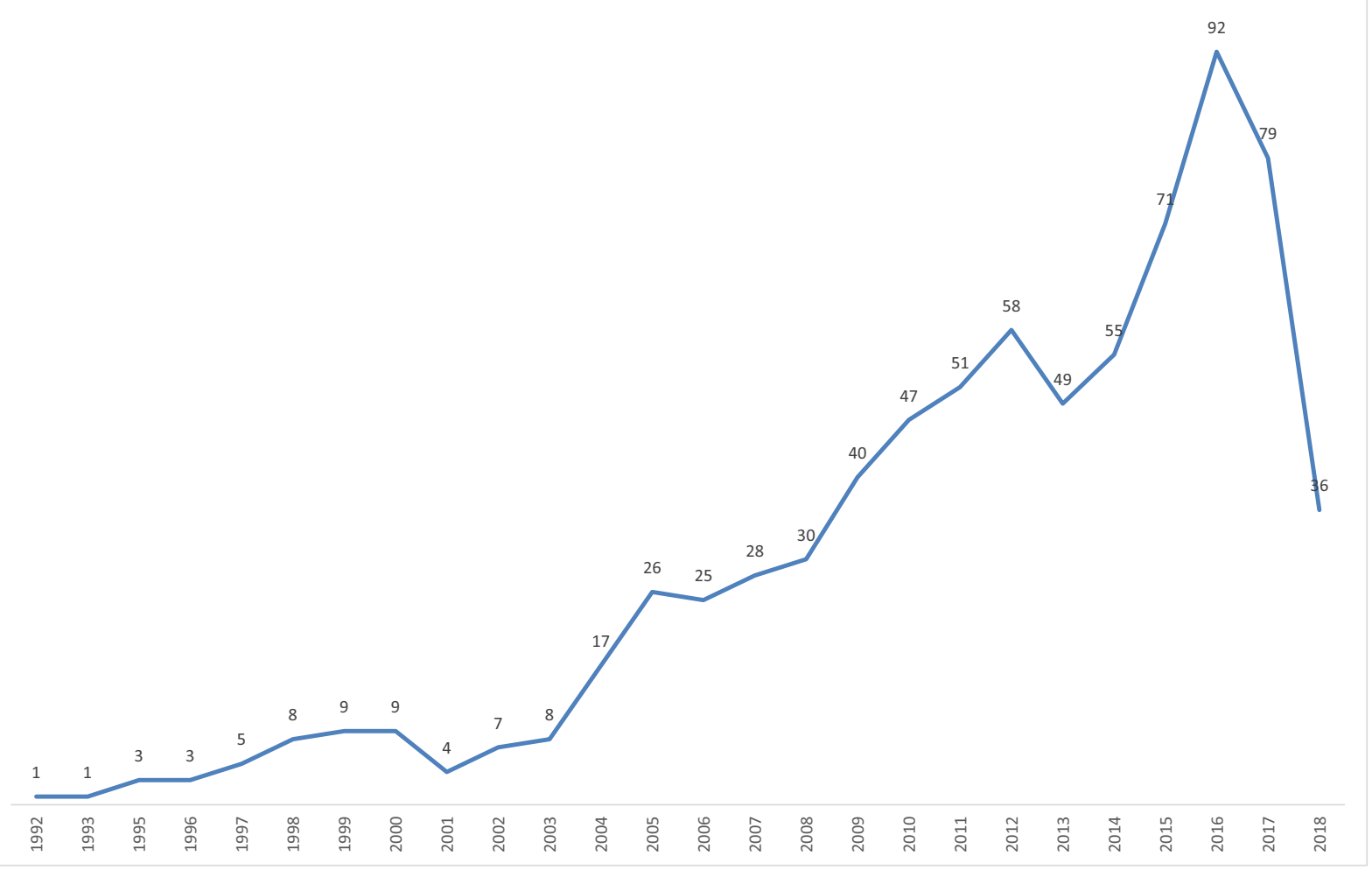

Fig. 2 Number of publications per year

two-dimensional coordinates result from the frequencies of their mutual appearances in the sampled papers and the "bubble" is their absolute frequency of appearances. The two-dimensional map demonstrated research topics arranged in three distinctive streams. The first and one of the most pertinent research streams deals with performance including topics such as marketing, management, entrepreneurship, performance, relationships, resources, network, experience, and market. The second, also one of the most important research streams, is about manufacturing including topics such as innovation, technology, industry, development, competition, advantage, and quality. Finally, the third stream is about institutions including topics such as Europe, China, barriers, integration, production, and trade.

In order to get additional information about the study methods in this field, Fig. 4 is demonstrating the frequency of each topic and its particular distance to quantitative study marker. Quantitative marker is designed as a combination of various keywords representing the quantitative type of study: quantitative, regression, correlation, panel analysis, panel data, statistic, numerical, econometrics, mathematics, convexity, Lagrange, standard error, general equilibrium, heteroscedastic, game theory, optimization, least square, linear, non*linear, geometric, rational choice theory, equation, and Bayesian. Coordinates derived for for the construction of the intellectual map were used to calculate distances between each topic and constructed qualitative study marker. The entire figure may be divided into four quadrants. The top left quadrant is about topics of low interest for further quantitative studies in the field (high frequency, low distance) which are considered significantly researched. The bottom left quadrant is about emerging topics and possible gaps in the literature. The bottom right quadrant is about relevant gaps in quantitative studies of the field, and finally the top right quadrant is about popular topics and relevant gaps in quantitative studies. According to the results in Fig. 4, topics of low interest are strategy, market, export, performance, relationships, development, network, entrepreneur, knowledge, foreign, resource-based view, and policy. Emerging topics and possible gaps in the literature are new ventures, growth, location, emerging, opportunities, risk, marketing, manufacturing, learning, information, capabilities, success, government, public, barriers, and Europe. Relevant gaps in qualitative studies are e- 
Table 1 Sources with the highest number of records

\begin{tabular}{|c|c|}
\hline Name of the journal & $\begin{array}{l}\text { No. of } \\
\text { records }\end{array}$ \\
\hline Journal of International Entrepreneurship & 37 \\
\hline International Business Review & 33 \\
\hline International Marketing Review & 28 \\
\hline $\begin{array}{l}\text { Journal of Small Business and Enterprise } \\
\text { Development }\end{array}$ & 20 \\
\hline Journal of Small Business Management & 20 \\
\hline International Small Business Journal & 18 \\
\hline Journal of World Business & 17 \\
\hline Small Business Economics & 17 \\
\hline Entrepreneurship and Regional Development & 14 \\
\hline $\begin{array}{l}\text { International Entrepreneurship and Management } \\
\text { Journal }\end{array}$ & 11 \\
\hline Journal of Business Research & 11 \\
\hline Journal of International Marketing & 11 \\
\hline European Journal of International Management & 10 \\
\hline Industrial Marketing Management & 8 \\
\hline Journal of International Business Studies & 8 \\
\hline Entrepreneurial Business and Economics Review & 7 \\
\hline European Journal of Marketing & 7 \\
\hline Management Decision & 7 \\
\hline Research Policy & 7 \\
\hline Transformations in Business \& Economics & 7 \\
\hline
\end{tabular}

business, service, entry, cooperation, cluster, trade, and institutions. Finally, popular topics and relevant gaps in quantitative studies are technology, competition, management, and innovation.

\section{Systematic literature review results}

Our systematic review classifies SME and IE research findings into three categories: subjects, theories, and methods (Table 4).

\subsection{Subject level}

At the subject level, we categorized research into ten broad categories of (1) entry modes, (2) human capital, (3) networks, (4) knowledge, (5) cognitive, (6) promotion, (7) geography, (8) capitalist, (9) technology, and (10) dimension. These broad codes conveyed a broad range of studies pertaining to SMEs and IEs. For example, research relating to entry mode such as "true born global" or "apparently born global" (Kuivalainen et al. 2007), networks (Dana 2001), and cognitive matters (Fayolle and Liñán 2014; Liñán and Fayolle 2015) are not new and have dominated SME and IE research efforts for some time. Correspondingly, in our analysis, we detected three significant trends and four key gaps in the literature. These will now be explained.

Firstly, there is a noticeable and growing interest in knowledge management (KM) in SMEs (Cerchione et al. 2016; Desouza and Awazu 2006; Durst and Runar Edvardsson 2012; Soto-Acosta et al. 2014). Secondly, there is growing emphasis on the human capital aspects of SMEs. Human capital theory (Becker 1964) postulates that human capital increases a worker's productivity in all tasks and that people with higher-quality human capital perform better at executing relevant tasks. Consequently, human capital pertains to individual knowledge and capabilities that allow for change in action and economic growth and includes the "training, experience, judgment, intelligence, relationships, and insight of individual managers and workers in a firm" ((Barney 1991), p. 101). Superior human capital is now acknowledged as paramount for effective SME internationalization (Ruzzier et al. 2007). Moreover, while SME studies involving human capital have typically centered on the entrepreneur (Westwood and Linstead 2001), less attention has been paid to the workers within SMEs. Thus, while the human capital theory has been applied to SMEs, the application and extent of examination has been incomplete. Thirdly, motivational studies (categorized within the framework of cognitive studies) are playing an increasingly important role in SME internationalization (Bell et al. 2003) and entrepreneurs (García-Lillo et al. 2017). There are a variety of motivational factors that have been identified to be important in SME internationalization, but the most momentous is the need for IEs to have a "global mindset" (Nummela et al. 2004). Conversely, the motivation to internationalize can be easily thwarted by ethnicity (Pangarkar 2008), religion (Welsh and Raven 2006), and language barriers (Knowles et al. 2006).

The first conspicuous gap in the literature concerns emerging markets. Caputo et al. (2016a, b) focus on the internationalization of firms from central and Eastern Europe, but the majority of IE and SME studies have focused on developed countries and have yet to pay attention to emerging markets (Ramamurti 2012). From a research standpoint, Javalgi and Todd (Javalgi and Todd 2011) make a case that more work is needed to 
Table 2 Most influential authors by the number of citations

\begin{tabular}{|c|c|c|c|}
\hline Author & No. of papers & No. of citations & No. of citations per one record \\
\hline Wright, $\mathrm{M}$ & 5 & 617 & 123 \\
\hline Westhead, P & 4 & 589 & 147 \\
\hline Ucbasaran, D & 3 & 588 & 196 \\
\hline Bell, J & 7 & 442 & 63 \\
\hline Fernandez, Z & 2 & 386 & 193 \\
\hline Nieto, MJ & 2 & 386 & 193 \\
\hline Lee, $\mathrm{S}$ & 2 & 383 & 192 \\
\hline Igbaria, M & 1 & 343 & 343 \\
\hline Iivari, $\mathrm{J}$ & 1 & 343 & 343 \\
\hline Antoncic, B & 6 & 340 & 57 \\
\hline Ruzzier, M & 6 & 340 & 57 \\
\hline Park, G & 1 & 336 & 336 \\
\hline Park, J & 1 & 336 & 336 \\
\hline Yoon, B & 1 & 336 & 336 \\
\hline Pett, TL & 5 & 324 & 65 \\
\hline Wolff, JA & 5 & 324 & 65 \\
\hline Jones, MV & 3 & 293 & 98 \\
\hline Hisrich, RD & 3 & 291 & 97 \\
\hline Loane, S & 6 & 287 & 48 \\
\hline Crick, D & 5 & 272 & 54 \\
\hline
\end{tabular}

add to the existing body of knowledge about the strategic importance of entrepreneurial orientation of SMEs in the emerging market. Previous research has not addressed the fact that emerging SMEs have different access to resources, capabilities, and networks and often operate under a diverse range of government policies (Dana et al. 2008). This area of studying is becoming particularly important as the governments of emerging countries continue to implement macroeconomic policies to help SME diversification (Callen et al. 2014). These policies are attempting to offer a stable macroeconomic environment; support the business setting; advance infrastructure, education, and skills; target the development of specific sectors; and promote entrepreneurship through SMEs ((Callen et al. 2014), p 18).

The second gap refers to the scant attention that has been afforded to comparative country and cultural studies, the third gap is the neglected regional areas within developed countries, and the fourth gap is the token attention that has been paid to low-tech industries in developed countries. For instance, there are a number of studies that have examined exporting activities of complex urban manufacturing SMEs with high-technology- based products (McDougall 1989) and focused on international new ventures (Oviatt and McDougall 1994), for example, oil (Cumbers et al. 2003) and Pharma (Mangematin et al. 2003), but few studies have focused on low-tech industries typically often found in regional areas (exceptions include (Cuerva et al. 2014; Van de Vrande et al. 2009)). Due to the bias of previous research towards high-tech SMEs in urban areas, there is the possible risk that the support provided by scholars, policymakers, and practitioners alike may be exclusively tailored towards high-tech manufacturing urban SMEs and inappropriate for low-tech firms.

\subsection{Theoretical level}

At the theoretical level, we identified a dominance of six key theories: (i) Uppsala model, (ii) born global, (iii) network theory, (iv) transaction cost theory (TCT), (v) entrepreneurial theory, and (vi) resourced-based view (RBV). However, a key problem is that five of the six consider that globalization is a gradual and incremental process throughout which a SME or IE can gain experience, accumulate resources, and develop the 
capabilities required for global operations. The globalization of markets (Levitt 1983), however, and of competition (Ohmae 1990) radically reduces the time span, and consequently, these theories fail to help our understanding of the constraints that the SMEs may experience in their ability to control their own development paths. Indeed, there is an increasing amount of evidence that SMEs and IEs, despite possessing limited resources, are aiming at rapid globalization (Kuivalainen et al. 2007). Accordingly, the limitations and applicability of these well-established theories for SMEs need to be questioned (McDougall et al. 1994). Conceivably, the human capital theory - that advocates continual development of capabilities that allow for change in actionis plausibly better placed in such a dynamic context.

Network theory states that knowledge-based business service firms (in particular) achieve competitive advantage by developing mutually supportive interactions with other service firms (Coviello 2006; Coviello and Martin 1999). This theory has illuminated the importance of affiliations and external links for the SME and personal connections, and inter-organizational arrangements have been argued to considerably assist the growth of SMEs. The network theory has repeatedly been proven to be useful in understanding the expansion and success of SMEs and IEs (Young et al. 2003). According to Dana (Dana 2001), as the drivers of globalization are removing barriers, SMEs are joining international networks which are presenting them with unparalleled openings and opportunities. Dana (Dana 2001) presents an example of the airline industry, where such relationships have become very common, as smallscale airlines provide elements of the value chain to MNCs by way of sub-contracting or franchising. Entrepreneurial theories have helped uncover why some SMEs are successful and others fail.

The widespread use of the network viewpoint is defensible since formal or informal networks may be mechanisms employed by SMEs to overcome resource constraints that they encounter. While network theory offers a good understanding of the internationalization phenomena through interpretation of the relationship between issues such as the liability of foreignness and the liability of outsidership (Sinkovics et al. 2018; Yamin and Kurt 2018), their application has been somewhat limited. We see that further studies utilizing network theory could be very useful particularly in emerging markets where limited networks have been identified as a major obstacle (Senik et al. 2011). 


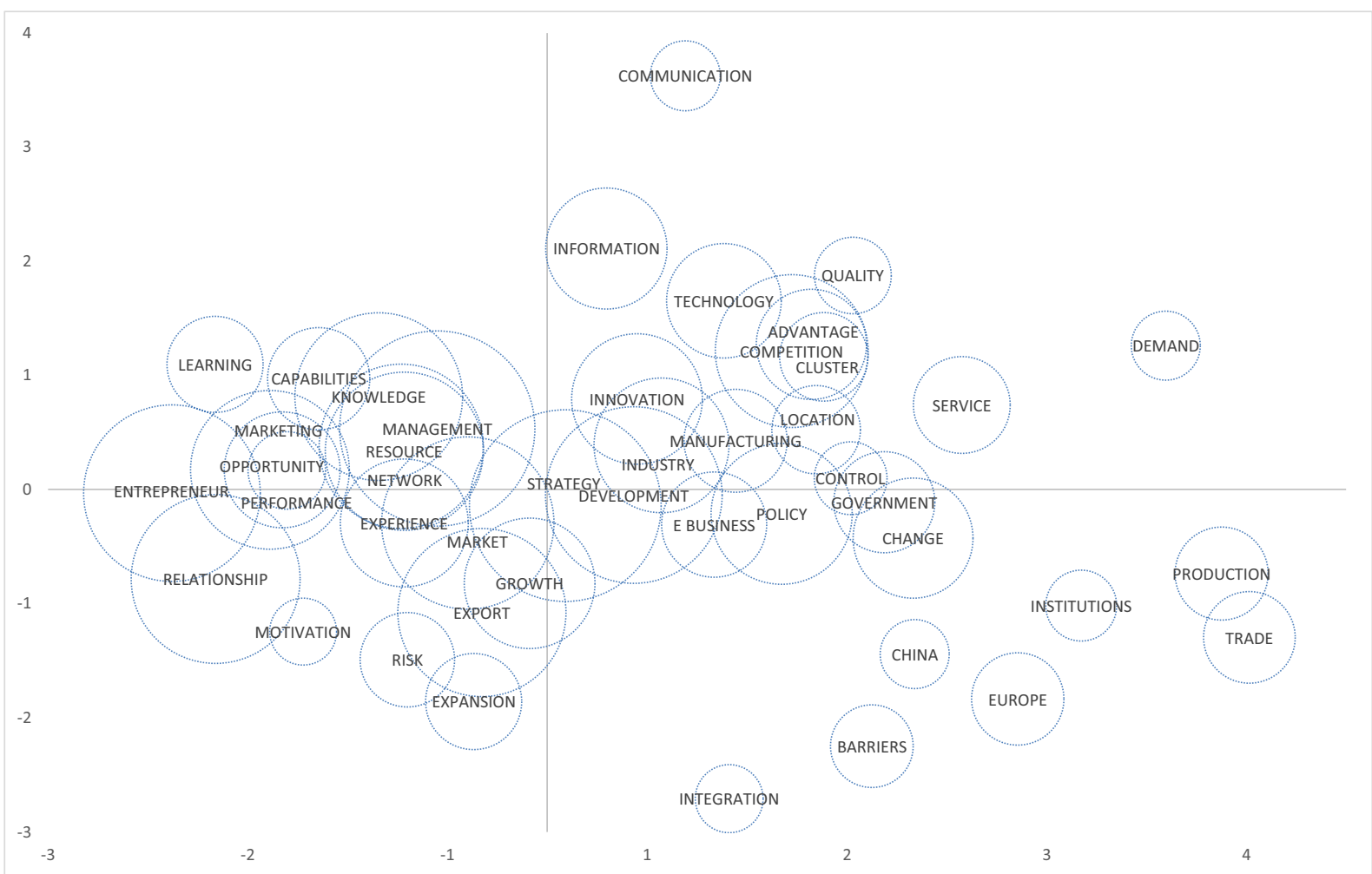

Fig. 3 Intellectual map of the research field

Notwithstanding, by far the most expended theory in our analysis is the resource-based view (RBV) (Barney and MacKey 2005, 2016). The RBV proposes that resources be characterized as simultaneously valuable, rare, non-substitutable, and inimitable, and when organizations' physical assets, infrastructure, and workforce satisfy these criteria, they qualify as resources (Barney and MacKey 2005). One the one hand, it has been found that the RBV is a valid framework that can be used to illuminate the activities of SMEs (Kraus et al. 2011) and has a degree of fit to the SME context because it can capture the informality in SMEs, and focuses on the pivotal role of the owner-manager (Nolan and Garavan 2016).

On the other hand, there has been a tendency to over simplify assumptions when drawing conclusions from RBV (Priem and Butler 2001), and it has been suggested that the RBV does not meet the empirical content criterion required of legitimate theoretical systems (McKelvey 1997). Another important point to raise at this point is that traditional RBV research has focused mainly on MNCs and is probably less applicable to SMEs (Kraus et al. 2011). In order to reduce these limitations, Nolan and Garavan (Nolan and Garavan
2016) suggest that "complex RBV" (Colbert 2004) represents a significant extension of the RBV that fits better with the SME context.

\subsection{Method level}

At the method level, we found a mixture of conceptual and empirical studies (Table 5). Empirical articles were those that dealt with primary data collection of a quantitative or qualitative nature (i.e., original empirical research, ethnographic studies, and case studies). While the method level will be determined by the researchers' desire to explore a new phenomenon or generalize an existing phenomenon (Collis and Hussey 2013) - and we did detect that multiple research designs have been used in the empirical studies - the vast majority of studies in our analysis were quantitative. Additionally, our analysis found that longitudinal studies focusing on SMEs are rare. Additionally, many of the studies were exploratory and did not lead to the generation of research propositions and lack generalization. The empirical studies generally required "explanatory" power. This may indicate the relative immaturity of the topic. 


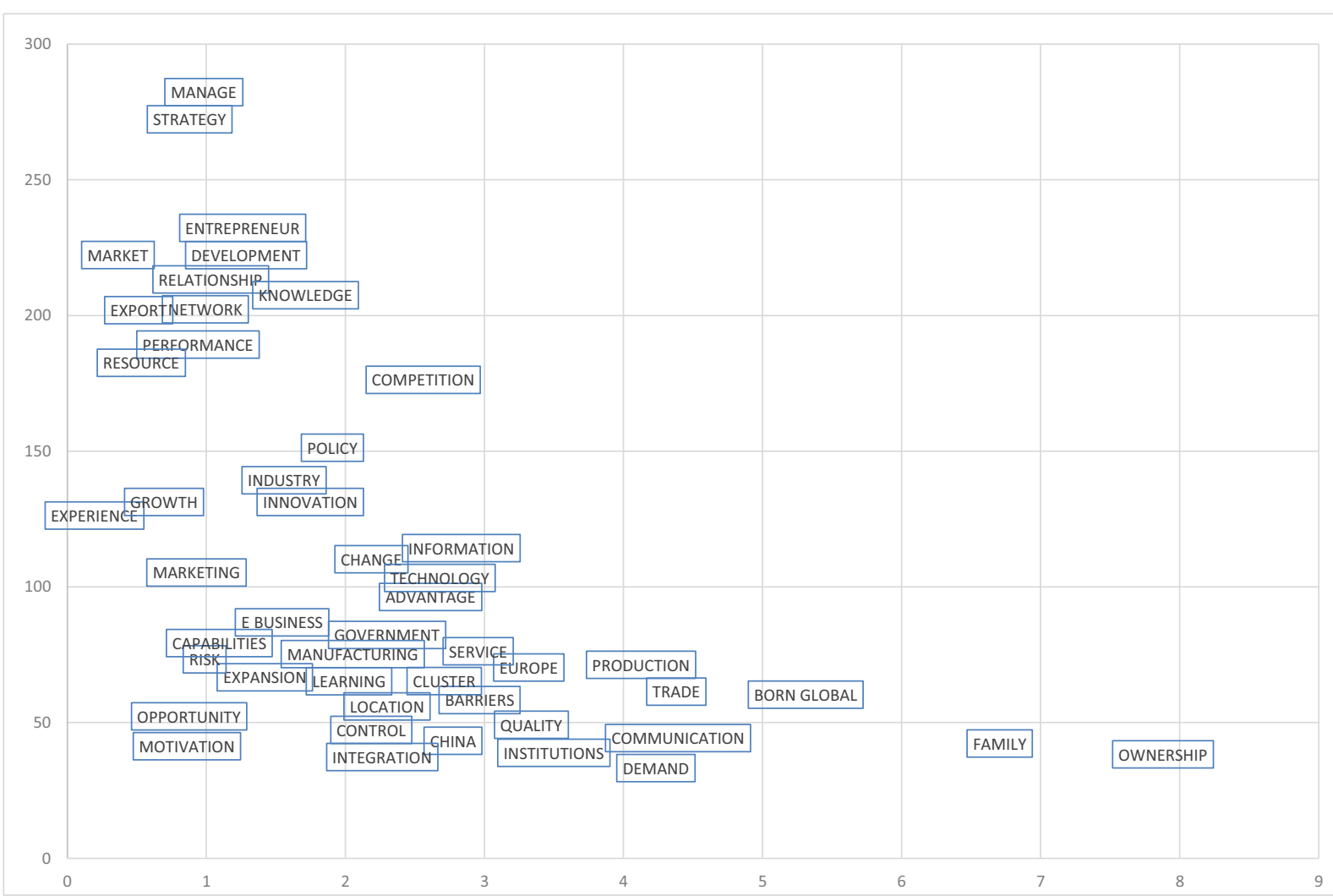

Fig. 4 Topic distance to quantitative marker

\section{Discussion}

Our systematic and thorough review of the literature identifies important progress in understanding the internationalization of SMEs. There is mounting evidence that certain SME activities can greatly impact their ability to internationalize. Yet, at the same time, our review also reveals that the bulk of the SME literature is very fragmented (Cerchione et al. 2016; Nolan and Garavan 2016; Stoian et al. 2018), and there are

Table 4 Key subjects, theories, and methods of the systematic literature review analysis

\begin{tabular}{lll}
\hline Subjects & Theories & Method \\
\hline $\begin{array}{l}\text { Cognitive, } \\
\text { contextual, SME } \\
\text { internationalizatio- } \\
\text { n, human capital, } \\
\text { INVs, global }\end{array}$ & $\begin{array}{l}\text { global theory, } \\
\text { network theory, } \\
\text { transaction cost }\end{array}$ & $\begin{array}{c}\text { Conceptual, } \\
\text { empirical-mo- } \\
\text { stly quantitative } \\
\text { theory, }\end{array}$ \\
$\begin{array}{l}\text { knowledge and } \\
\text { networks }\end{array}$ & theory, and RBV & \\
\hline
\end{tabular}

substantial knowledge gaps at subject level, theoretical level, and methodological level. These three levels will now be discussed in more detail.

\subsection{Subject level}

In moving forward, from a subject perspective, there is scope for future SME research to pay particular attention to (1) knowledge transfer, (2) human resource development, and (3) refocusing geographical attention, in general topics that are critical to SME future practice and policy, and offer specific directives for integrated and multilevel studies of characteristics, antecedents, and outcomes. These subjects will now be discussed in a little more depth.

\subsection{Knowledge transfer}

Knowledge management and learning processes have become a major factor for achieving long-term competitive advantage and for international success. Although the literature in general focuses on the knowledge 
Table 5 Major codes of descriptors

\begin{tabular}{|c|c|}
\hline Major codes & Descriptors \\
\hline ENTRY MODE & $\begin{array}{l}\text { Entry, expansion, export, globali?ation, } \\
\text { growth, process, ventures, strategy, born } \\
\text { global, patterns, impact, intensity, patterns }\end{array}$ \\
\hline $\begin{array}{l}\text { HUMAN } \\
\text { CAPITAL }\end{array}$ & $\begin{array}{l}\text { Capabilities, experience, labor, learning, } \\
\text { manage, performance, policy, resource, } \\
\text { rights, support, work, opportunities, trade }\end{array}$ \\
\hline NETWORKS & $\begin{array}{l}\text { Ties, network, relationship, government, } \\
\text { intensity }\end{array}$ \\
\hline KNOWLEDGE & Knowledge, information \\
\hline COGNITIVE & $\begin{array}{l}\text { Orientation, perspective, logic, insights, } \\
\text { challenges, success }\end{array}$ \\
\hline PROMOTION & $\begin{array}{l}\text { Business, company, competition, corporate, } \\
\text { industry, service, sector, organization, } \\
\text { marketing, market, manufacturing, service }\end{array}$ \\
\hline GEOGRAPHY & $\begin{array}{l}\text { Country, location, China, foreign market, } \\
\text { international, world, barriers }\end{array}$ \\
\hline CAPITALIST & Economy, investment, risk, emi, entrepreneur \\
\hline TECHNOLOGY & e-business, ICT, technology, ERP, innovation \\
\hline DIMENSION & $\begin{array}{l}\text { Size, SME, small firms, medium sized, } \\
\text { enterprises, small firms }\end{array}$ \\
\hline
\end{tabular}

management systems used by SMEs, the point of view of the individual SMEs is rarely considered. Questions remain unanswered in regard to the methods used and the way in which they are used (Durst et al. 2015). It has been recognized for some time that knowledge transfer within organizational settings is a vital process (Kogut and Zander 1992), and evidence implies that firms that can make full use of their collective knowledge are likely to be successful innovators (Grant 1996); yet our understanding of knowledge practices in SMEs remains quite underdeveloped.

Knowledge transfer in MNCs is facilitated by global mobility of staff (Reiche 2012); however, knowledge transfer in SMEs is poorly understood. Yet, it has been demonstrated that SMEs have very strong needs for both external knowledge and inter-organizational knowledge transfer (Chen et al. 2006). Knowledge transfer is entrenched in the SMEs' ability to form networks (Freeman et al. 2006) and technology transfer; R\&D development offers particularly significant paybacks of efficient knowledge transfer for SMEs (Loane and Bell 2006). It is of prime importance for the internationalization of SMEs (Wright et al. 2007). Nonetheless, we must be mindful that global mobility may present a complex situation for many SMEs, particularly if they are in the early stages of internationalization. For instance, they may not have the inclination, capability, or financial means to transfer staff globally. This situation suggests something of a chicken-and-egg scenario. The SME needs to relocate its staff globally to enable transfer knowledge and at the same time needs this knowledge in order to internationalize.

In line with Sapienza et al. (Sapienza et al. 2006), we suggest that knowledge transfer brought back by returning employees in SMEs can be used as a platform to fast-track internationalization and overcome issue of liability of foreignness. Hence, we find that global performance of these firms may be dependent upon staff global mobility involving knowledge transfer from overseas back to the SME. Therefore, in order to create and process knowledge, SMEs should make it a strategic priority for their staff to gain international experience. However, that assertion will be dependent on a number of factors including their size, the location of the SME, the location of the export destination, industry sector, and financial means (Child and Rodrigues 2007). It will also be dependent upon market entry forms, such as franchising, licensing, direct investments, and alliance agreements (Hollenstein 2005). While setting up a sales subsidiary in a foreign country is typically a later stage of internationalization not within the means of the SME (Johanson and Vahlne 1977), improving their relationship with the operational partners and intermediaries can often be achieved with occasional faceto-face contact (Mole 2002). This endeavor will help improve the relationship with the agent or customer and build trust which is well recognized as being imperative for SME internationalization success. According to Child and Rodrigues (Child and Rodrigues 2007), "having the help of a trusted local person with the appropriate tacit knowledge and/or informal contacts within the foreign system can considerably facilitate the conduct of business there." In addition, the SME employee will gain imperative international experience. Our intention is that staff within a SME should understand the nuances of international business and that it is advantageous if they can make face-to -face contact and visit their distributors, agents, and end customers.

\subsection{Human resource development}

While human resource development (HRD) in SMEs has received attention in the media (O'Connell 2014) and various business associations such as the 
"Federation of Small Businesses" and the "Management Development Council," research on HRD in SMEs does not appear to have examined other organizational dimensions apart from firm size. In particular, researchers have not thoroughly examined the extent of the influence of the critical role played by the owner-manager in HRD and especially the management of talent in SMEs. Certainly, the effort to attract, compensate, motivate, and retain employees is a daunting task for SMEs, particularly as the war for talent becomes highly competitive (Abraham et al. 2015). However, retaining and developing talent is important too. When a SME can effectively recruit and develop talent, it presents a very effective source of sustained competitive advantage (Ashton and Morton 2005; Collings and Mellahi 2009; Farndale et al. 2010). However, managing talent (termed talent management) has typically been described in terms of the MNCs, and research has been negligible in applying the talent management (TM) concept across SMEs (Valverde et al. 2013). Talent can be applied as an "exclusive" or "inclusive" concept (Iles et al. 2010), meaning that talent can be representative of a select few or everyone employed (Meyers and van Woerkom 2013). Although the debate is great, there is a common consideration for the fact that the word "talent" is a relative term (Iles et al. 2010) and that it insinuates "having more" than others have (Adamsen 2016).

Despite research having paid separate attention to both talent management and SMEs, the two subjects have rarely been studied together and comprehensive reviews of research on the two subjects are virtually non-existent. Thus, the momentum for a cross-disciplinary review of TM and SMEs is needed as SMEs depend on effectively managing the talent of a group of people (Dabić et al. 2011). Accordingly, an understanding of what TM means and how it can best be implemented is important for SMEs. We argue that the combined fields of TM and SMEs require better exploration and articulation, especially the multifaceted question of whether a SME should decide to adopt an exclusive or inclusive approach to TM. This represents a critical gap that future work must address. Our assertion in this regard stems directly from the recognition that the differences between MNCs and SMEs are more than the size in MNCs.

\subsection{Refocusing geographical attention}

While we acknowledged earlier that geographical attention needs to be diverted to developing countries, we also make a case for regional focus on SMEs within developed countries. SMEs are increasingly fueling economic growth and innovation in developing countries (Hendrickson et al. 2015). However, there is evidence that regional areas within developed countries may be performing very poorly in this regard (Bloch and Bhattacharya 2016). Regional entrepreneurs and small business owners/managers often face a different set context of institutional, resource, and market conditions than their urban counterparts and can typically have more difficulty with access to customers and suppliers; knowledge spillovers through networking and R\&D institutions; cost advantages of urban agglomeration such as skilled labor, accessible transport, and access to capital (particularly venture capital). Regional entrepreneurial ecosystems are not only largely overlooked by scholars and policymakers, but the policies and processes required for their effective development are often very different from urban or peri-urban ecosystems.

\subsection{Theoretical level}

A case could be made that there has been an overreliance on RBV theory (Bloodgood et al. 1996). Few studies have investigated the suitability and boundaries of the RBV for SME and IE research by considering the characteristics of these disciplines and how they may affect the operational validity of the RBV for practitioners. Hence, we contend that there is ample scope to build on RBV in relation to SME and entrepreneurship and also for the development of completely new theories. Terjesen et al. (2016a, b, p.13) in their analysis of comparative IEs found that despite the development of several theoretical models in comparative research, there is a paucity of the most prominent theories from management, international business, and entrepreneurship as well as from related fields, such as economics, finance, and sociology. This paradigm is also true of SME internationalization literature.

\subsection{Method level}

It is interesting that researchers have preferred to use quantitative methods despite the closely related subject of strategic management scholarship now showing a preference for qualitative studies. We are not sure why this is the case. One assumption is that quantitative studies are preferred as much, as SME research has 
tended to be concerned with quantitative findings, for example, with the performance and job creation of small firms, with the numbers of small firms concerned with the take-up and use of support schemes, with the numbers of firms that are using different forms of finance, and with the numbers of growing small firms (Deakins et al. 2002). Another possibility, perhaps more specific to emerging SME studies, is that unlike MNCs, SMEs are unlikely to be run by IT systems that would more easily facilitate survey participation (Tatoglu et al. 2016). On the other hand, O'Donnell and Cummins (O’Donnell and Cummins 1999) offer a useful insight and contend that if we are to appropriately address the issue of SME activities, we must look beyond quantitative studies. They argue that SME research needs to allow the phenomenon to be examined within its social context; allow the phenomenon to be examined in its totality; allow the researcher to get close to the participants; be sensitive to the holistic nature of the phenomenon; be carried out longitudinally. We contend with another 20 years insight that this is indeed sound advice, yet it appears to have been largely overlooked by SME scholars. One downside of the continual predominance of quantitative studies according to O'Donnell and Cummins (O'Donnell and Cummins 1999) is that this research method has probably created more questions than it has answered.

\section{Future research directions}

Our review of the existing body of SME internationalization research reveals ample opportunities for future examination, and owing to the under-researched phenomenon of certain aspects of SME internationalization, the results of this study open up several new questions. Following the structure of the above review of the current status of research, we highlight knowledge gaps and suggest directions for future research with respect to (1) subject, (2) theory, and (3) methodology.

At the subject level, there remains much to be done in terms of improving our understanding of how best human capital can be developed to increase the chances of successful internationalization of SMEs. Human capital theory could be integrated with economic perspectives to assess the importance of different types of human capital for translating entrepreneurship into growth (Terjesen et al. 2016a, b). Likewise, HRD as a competitive advantage could also have great scope for future
SME researchers. For example, the strategic management of talent in SMEs has emerged as a critical element and is almost a tabula rasa for future SME scholars. The theme of exclusive or inclusive TM could have wider implications for the SME internationalization, and while we think that this is an important debate, we would like to highlight that in regard to SMEs, we reject the prescriptive exclusive approach to TM so often prevalent in the TM literature. Nonetheless, we add the ROI of TM ambitions needs further examination, and it is important to stress that for HRD and TM to be championed as valuable disciplines by SMEs, their relationship with business performance and ultimately the bottom line must be simplified and understood. In other words, more work needs to be done across the sustainable benefits of firm-specific competencies and capabilities that SMEs develop. Consequently, scholars need to position the benefits of HRD in internationalization by expounding its value - both short term and long term in order to be understood by entrepreneurs and managers of SMEs. In general, research must consider the restraints and ambiguities facing HRD and the management of talent in SMEs and recognize that these processes differ greatly from the issues bounding HRD and talent in MNCs. Furthermore, few studies have analyzed the conjuncture of culture and effective internationalization, leaving an obvious calling for more research in this area, for example, an examination of national culture in regard to how mind-set, motivation, and ambition are formed by a particular culture. Focusing on these knowledge gaps could be important to understand the full set of human capital theory components involved in internationalization of SMEs in order to develop optimal SME internationalization strategies in different country settings. There is also considerable scope for SME scholars to develop KM transfer studies in SME internationalization. Problem solving strategies are needed to improve the SME's ability to acquire external knowledge, create external networks, manage the complexities of global mobility, and enable internationalization. Consequently, further studies should shed light on the knowledge transfer in relation to problem-solving strategies in internalization. Importantly, the three subject categories (HRD, TM, and KM) are not independent, and there is a degree of dependence between the future proposed research themes.

At the theory level, scholars need to investigate the suitability and boundaries of the RBV for SME and IE research by considering the characteristics of these 


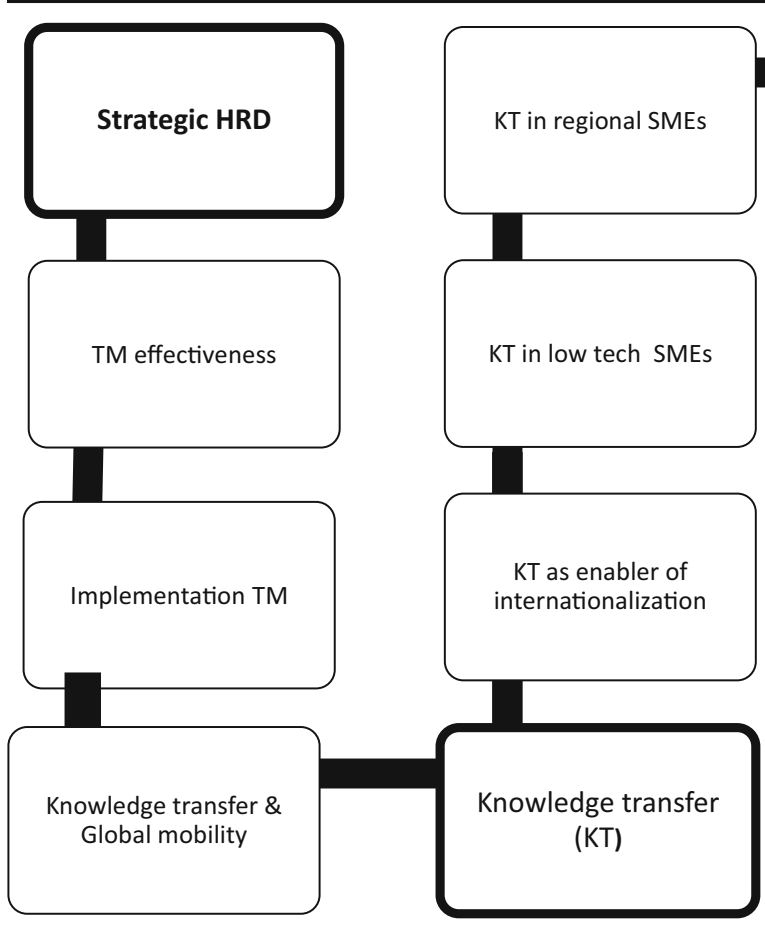

Fig. 5 The future themes for SME research

disciplines and how they may affect the operational validity of the RBV for practitioners. Research may also benefit from a "complex RBV" (Colbert 2004) including extensions and combinations of RBV-such as permutations of the RBV, dynamic capabilities theory, and absorptive capacity. Dynamic capabilities (Teece 2007) have started to receive attention from researchers; there remains more scope for this useful theory. It involves resource development and renewal and is particularly pertinent to SMEs. According to Cepeda-Carrion et al. (Cepeda-Carrion et al. 2012), a firm's absorptive capacity involves engaging in new practices; hence, employees need to have the flexibility to adapt to new practices that are likely to differ from those that already exist and are familiar. Therefore, a fundamental premise of absorptive capacity is that the firm will be more flexible and innovative through obtaining and applying external knowledge. Thus, we see that there is further latitude for SME studies encompassing dynamic capabilities and absorptive capacity. Overall, we contend that there is ample scope to build on RBV in relation to SME and entrepreneurship and also for the development of completely new theories. Indeed, there is a clear call for new models using a wider variety of theories in order to explain and expand the phenomenon of internationalization. Moreover, these new scholarships could build on concepts such as the complex RBV, advance the application of network theory, or develop novel theories relevant to SME internationalization. As suggested by Terjesen et al. (2016a, b, p.13), researchers could borrow theories from management, international business, entrepreneurship strategy, economics, finance, and sociology.

At the method level, we suggest greater attention be placed on qualitative studies. The use of qualitative methods is argued to hold much promise in international business studies (Birkinshaw et al. 2011). While the literature has developed some noteworthy models, we argue that these tend to be broad-spectrum with largely untested propositions. The numerous quantitative studies we analyzed invariably tested theories; they did not develop new theories; qualitative research is essentially an inductive approach to theory generation. The emphasis veers to dynamic processes, with the purpose of clarifying, rather than predicting phenomena (Leavy 1994). Consequently, qualitative studies are desperately needed to develop new theories and increase "explanatory" power. It is evident in SME and IE studies that we need to know more about "how" and this is answered by qualitative studies. Qualitative methodology is appropriate for exploratory studies (Creswell 2013) and could be particularly helpful to improve our understanding of 
SMEs (Shavelson et al. 2002) and could help verify concepts or refute them (Flyvbjerg 2006). Case study methodology could also be useful in SMEs and may help with theory extension (Piekkari and Welch 2011).

For example, SME qualitative researchers could interview owner-managers to establish important matters in SMEs. Additionally, we urge scholars and practitioners to work together and across countries, cooperating with interested agencies and associations to develop new longitudinal, multilevel data sets and introduce dual qualitative/quantitative approaches and new diverse, sophisticated analytical tools. An interactive Delphi process could be employed to seek the opinions of a panel of experts on the research priorities for SMEs and IEs. The Delphi process was established by the Rand Corporation during the cold war to forecast the impact of technology on warfare. It is an interactive forecasting method based on the opinions of selected experts. The content analysis of the results could conceivably identify novel directions for future research in the SMR and IE field. According to Dana and Wright (Dana and Wright 2008), the compilation of the recommendations received from the panelists could provide a wealth of ideas and guidelines for specific research projects. Additionally, more longitudinal studies could be helpful in examining SMEs over an extended period and may be useful in identifying differences in challenges over time (Terjesen et al. 2016a, b).

Figure 5 summarizes the individual topical opportunities. This agenda exemplifies that there is a necessity for more in-depth research to both augment theory building and afford new academic visions for SME internationalization research at the various levels discussed above. In this way, future research will construct valuable typologies and paradigms that help the managers of SMEs to better understand the challenges of internationalization.

\section{Conclusion}

This paper has focused on the pathways of SME internationalization. Clear evidence was found that demonstrates that the SME and entrepreneurship literature is highly fragmented with substantial knowledge gaps related to content, theory, and methodology, for which we outline a detailed future research agenda. Thus, this paper makes important contributions to the literature in terms of extending the current dominant theoretical perspectives. Firstly, it proposes that there is a heterogeneous nature of SME and entrepreneurship within countries. Secondly, the heterogeneous nature helps explain outcomes at firm level (e.g., financial and export performance) and country level (e.g., economic growth), as well as antecedents at the country level (e.g., certain aspects of cultural differences). Thirdly, it proposes new lenses from management, international business, and entrepreneurship. We believe this is a valuable endeavor as it will, we hope, influence more focused empirical research.

The main limitation comes from our initial search. We focused only on articles and review covered by Web of Science Core Collection, but that database does not cover all journals from their foundation.

Open Access This article is distributed under the terms of the Creative Commons Attribution 4.0 International License (http:// creativecommons.org/licenses/by/4.0/), which permits unrestricted use, distribution, and reproduction in any medium, provided you give appropriate credit to the original author(s) and the source, provide a link to the Creative Commons license, and indicate if changes were made.

\section{References}

Abraham, M., Kaliannan, M., Mohan, A. V., \& Thomas, S. (2015). A review of Smes recruitment and selection dilemma: finding a'Fit'. The Journal of Developing Areas, 49(5), 335-342.

Adamsen, B. (2016). Demystifying talent management: a critical approach to the realities of talent. Springer. https://doi. org/10.1057/9781137508676.

Ashton, C., \& Morton, L. (2005). Managing talent for competitive advantage. Strategic HR Review, 4(5), 28-31.

Barney, J. B. (1991). Firm resources and sustained competitive advantage. Journal of Management, 17, 99-120.

Barney, Jay \& Mackey, Tyson. (2005). Testing Resource-Based Theory. Research Methodology in Strategy and Management. 2, 1-13. https://doi.org/10.1016/S1479-8387 (05)02001-1.

Barney, J. B., \& Mackey, A. (2016). Text and metatext in the resource-based view. Human Resource Management Journal, 26(4), 369-378.

Becker, G. (1964). S. Human Capital: A Theoretical and Empirical Analysis, with Special Reference to Education. (3rd edition ) Published in January 1994 by The University of Chicago Press (C) 1994 by the National Bureau of Economic Research.

Bell, S. (2015). Small and medium enterprises (SMEs) finance, The World Bank Brief, available at: http://www.worldbank. org/en/topic/financialsector/brief/smes-finance. accessed 20 th of June 2017.

Bell, J., McNaughton, R., Young, S., \& Crick, D. (2003). Towards an integrative model of small firm internationalisation. Journal of International Entrepreneurship, 1(4), 339-362. 
Benzécri, J.-P. (1982). , 4th edition. Paris: Dunod.

Bilkey, W. J., and Tesar, G. (1977). The export behavior of smaller-sized Wisconsin manufacturing firms. Journal of International Business Studies, 8(1), 93-98.

Birkinshaw, J., Brannen, M. Y., \& Tung, R. L. (2011). From a distance and generalizable to up close and grounded: reclaiming a place for qualitative methods in international business research. Journal of International Business Studies, 42(5), 573-581.

Bloch, H., \& Bhattacharya, M. (2016). Promotion of innovation and job growth in small-and medium-sized enterprises in Australia: evidence and policy issues. Australian Economic Review, 49(2), 192-199.

Bloodgood, J. M., Sapienza, H. J., \& Almeida, J. G. (1996). The internationalization of new high-potential US ventures: antecedents and outcomes. Entrepreneurship Theory and Practice, 20(4), 61-77.

Bratkovic, T., Antoncic, B., \& Ruzzier, M. (2009). Strategic utilization of entrepreneur's resource-based social capital and small firm growth. Journal of Management \& Organization, 15(4), 486-499.

Brouthers, K. D., \& Nakos, G. (2004). SME entry mode choice and performance: a transaction cost perspective. Entrepreneurship Theory and Practice, 28(3), 229-247.

Buckley, P. J., \& Ghauri, P. N. (2004). Globalisation, economic geography and the strategy of multinational enterprises. Journal of International Business Studies, 35(2), 81-98.

Callen, M. T., Cherif, R., Hasanov, F., Hegazy, M. A., \& Khandelwal, P. (2014). Economic diversification in the GCC: past, present, and future. International Monetary Fund. https://www.imf.org/en/Publications/StaffDiscussion-Notes/Issues/2016/12/31/EconomicDiversification-in-the-GCC-Past-Present-and-Future-42531. Accessed 10th of August 2018.

Caputo, A., Pellegrini, M. M., Dabic, M., \& Dana, L. P. (2016a). Internationalization of firms from Central and Eastern Europe. European Business Review, 28(6), 630-651.

Caputo, A., Marzi, G., \& Pellegrini, M. M. (2016b). The internet of things in manufacturing innovation processes: development and application of a conceptual framework. Business Process Management Journal, 22(2), 383-402.

Castillo-Vergara, M., Alvarez-Marin, A., \& Placencio-Hidalgo, D. (2018). A bibliometric analysis of creativity in the field of business economics. Journal of Business Research, 85, 1-9. https://doi.org/10.1016/j.jbusres.2017.12.011.

Cavusgil, S. T., \& Knight, G. (2015). The born global firm: an entrepreneurial and capabilities perspective on early and rapid internationalization. Journal of International Business Studies, 46(1), 3-16.

Cepeda-Carrion, G., Cegarra-Navarro, J. G., \& Jimenez-Jimenez, D. (2012). The effect of absorptive capacity on innovativeness: context and information systems capability as catalysts. British Journal of Management, 23(1), 110-129.

Cerchione, R., Esposito, E., \& Spadaro, M. R. (2016). A literature review on knowledge management in SMEs. Knowledge Management Research \& Practice, 14(2), 169-177.

Chen, S., Duan, Y., Edwards, J. S., \& Lehaney, B. (2006). Toward understanding inter-organizational knowledge transfer needs in SMEs: insight from a UK investigation. Journal of Knowledge Management, 10(3), 6-23.
Child, J., \& Rodrigues, S. B. (2007). The process of SME internationalization: British firms entering Brazil. Revista Economia \& Gestão, 7(14), 31-55.

Colbert, B. A. (2004). The complex resource-based view: implications for theory and practice in strategic human resource management. Academy of Management Review, 29(3), 341358.

Collings, D. G., \& Mellahi, K. (2009). Strategic talent management: a review and research agenda. Human Resource Management Review, 19(4), 304313.

Collis, J., \& Hussey, R. (2013). Business research: a practical guide for undergraduate and postgraduate students. Macmillan International Higher Education. Red Globe Press, UK

Coviello, N. E. (2006). The network dynamics of international new ventures. Journal of International Business Studies, 37(5), 713-731.

Coviello, N. E., \& Jones, M. V. (2004). Methodological issues in international entrepreneurship research. Journal of Business Venturing, 19(4), 485-508.

Coviello, N.E. and Martin, K.-A. (1999) Internationalization of service SMEs: an integrated perspective from the engineering consulting sector. Journal of International Marketing 7(4): 42-66.

Coviello, N. E., \& McAuley, A. (1999). Internationalisation and the smaller firm: a review of contemporary empirical research. Management International Review, 39, 223-256.

Creswell, J. W. (2013). Research design: qualitative, quantitative, and mixed methods approaches. Thousand Oaks: Sage.

Cuerva, M. C., Triguero-Cano, Á., \& Córcoles, D. (2014). Drivers of green and non-green innovation: empirical evidence in low-tech SMEs. Journal of Cleaner Production, 68, 104 113.

Cumbers, A., Mackinnon, D., \& Chapman, K. (2003). Innovation, collaboration, and learning in regional clusters: a study of SMEs in the Aberdeen oil complex. Environment and Planning A, 35(9), 1689-1706.

Dabic, M., \& Bach, P. (2008). Understanding the foreign direct investment environments in EU $27+$ candidate country Croatia: the current determinants and patterns. International Journal of Entrepreneurship and Innovation Management, $8(3), 254-271$.

Dabić, M., Ortiz-De-Urbina-Criado, M., \& Romero-Martínez, A. M. (2011). Human resource management in entrepreneurial firms: a literature review. International Journal of Manpower, 32(1), 14-33.

Dabic, M., González-Loureiro, M., \& Furrer, O. (2014). Research on the strategy of multinational enterprises: key approaches and new avenues. BRQ Business Research Quarterly, 17(2), 129-148. https://doi.org/10.1016/j.brq.2013.09.001.

Dabic, M., González-Loureiro, M., \& Harvey, M. (2015). Evolving research on expatriates: what is "known" after four decades (1970-2012). The International Journal of Human Resource Management, 26(3), 316-337. https://doi. org/10.1080/09585192.2013.845238.

Dana, L.-P. (2001). Networks, internationalization \& policy. Small Business Economics, 16(2), 57-62.

Dana, L.-P., \& Wright, R. W. (2008). International entrepreneurship: research priorities for the future. International Journal of Globalisation and Small Business, 3(1), 90-134. 
Dana, L. P., Han, M., Ratten, V., \& Welpe, I. M. (2008). Towards a theory of internationalization for European entrepreneurship. In Handbook of research on European business and entrepreneurship. Edward Elgar Publishing.

Deakins, D., Morrison, A., \& Galloway, L. (2002). Evolution, financial management and learning in the small firm. Journal of Small Business and Enterprise Development, 9(1), 7-16.

Denyer, D., \& Neely, A. (2004). Introduction to special issue: innovation and productivity performance in the UK. International Journal of Management Reviews, 5(3-4), 131-135.

Desouza, K. C., \& Awazu, Y. (2006). Knowledge management at SMEs: five peculiarities. Journal of Knowledge Management, 10(1), 32-43.

Drisko, J. W., \& Maschi, T. (2016). Content analysis: pocket guides to social work research methods. New York: Oxford University Press.

Duriau, V. J., Reger, R. K., \& Pfarrer, M. D. (2007). A content analysis of the content analysis literature in organization studies: research themes, data sources, and methodological refinements. Organizational Research Methods, 10(1), 5-34.

Durst, S., \& Runar Edvardsson, I. (2012). Knowledge management in SMEs: a literature review. Journal of Knowledge Management, 16(6), 879-903.

Durst, S., Edvardsson, I. R., \& Bruns, G. (2015). Sustainable organisations and knowledge process outsourcing: conditions for success. International Journal of Knowledge and Learning, 10(2), 110-123.

Etemad, H., Wright, R. W., \& Dana, L.-P. (2001). Symbiotic international business networks: collaboration between small and large firms. Thunderbird International Business Review, 43(4), 481-499.

Farndale, E., Scullion, H., \& Sparrow, P. (2010). The role of the corporate HR function in global talent management. Journal of World Business, 45(2), 161-168.

Fayolle, A., \& Liñán, F. (2014). The future of research on entrepreneurial intentions. Journal of Business Research, 67(5), 663-666.

Flyvbjerg, B. (2006). Five misunderstandings about case-study research. Qualitative Inquiry, 12(2), 219-245.

Freeman, S., Edwards, R., \& Schroder, B. (2006). How smaller born-global firms use networks and alliances to overcome constraints to rapid internationalization. Journal of International Marketing, 14(3), 33-63.

Furrer, O., \& Sollberger, P. (2007). The dynamics and evolution of the service marketing literature: 1993-2003. Service Business, 1(2), 93-117.

Furrer, O., Thomas, H. A., \& Goussevskaia, A. (2008). The structure and evolution of the strategic management field: a content analysis of 26 years of strategic management research. International Journal of Management Reviews, 10(1), 1-23.

García-Lillo, F., Úbeda-García, M., \& Marco-Lajara, B. (2017). The intellectual structure of human resource management research: a bibliometric study of the international journal of human resource management, 2000-2012. The International Journal of Human Resource Management, 28(13), 1786-1815.

Gaur, A., \& Kumar, M. (2018). Systematic approach to conducting review studies: an assessment of content analysis in 25 years of IB research. Journal of World Business, 5(2), 280-289.
Gonzalez-Loureiro, M., Dabic, M., \& Furrer, O. (2015). A content and comparative analysis of strategic management research in the Baltic area: a research agenda for qualitative studies. Baltic Journal of Management, 10, 243-266.

Gonzalez-Loureiro, M., Sousa, M. J., \& Pinto, H. (2017). Culture and innovation in SMEs: the intellectual structure of research for further inquiry. European Planning Studies, 0(0), 1-24.

Grant, R. M. (1996). Toward a knowledge-based theory of the firm. Strategic Management Journal, Winter Special Issue, 17, 109-122.

Hendrickson, L., Bucifal, S., Balaguer, A., and Hansell, D. (2015). The employment dynamics of Australian entrepreneurship', Department of Industry and Science Research Paper 4/2015, Canberra.

Hoffman, D. J., \& de Leeuw, J. (1992). Interpreting multiple correspondence analysis as a multidimensional scaling method. Marketing Letters, 3, 259-272.

Hoffman, D. J., \& Franke, G. R. (1986). Correspondence analysis: graphical representation of categorical data in marketing research. Journal of Marketing Research, 23, 213-227.

Hoffman, D. J., de Leeuw, J., \& Arjunji, R. V. (1994). Multiple correspondence analysis. In R. P. Bagozzi (Ed.), Advanced methods of marketing research. Oxford: Blackwell.

Hollenstein, H. (2005). Determinants of international activities: are SMEs different?. Small Business Economics, 24(5), 431450.

Iles, P., Chuai, X., \& Preece, D. (2010). Talent management and HRM in multinational companies in Beijing: definitions, differences and drivers. Journal of World Business, 45(2), 179-189.

Javalgi, R. R. G., \& Todd, P. R. (2011). Entrepreneurial orientation, management commitment, and human capital: the internationalization of SMEs in India. Journal of Business Research, 64(9), 1004-1010.

Johanson, J., \& Vahlne, J.-E. (1977). The internationalization process of the firm-a model of knowledge development and increasing foreign market commitments. Journal of International Business Studies, 23-32.

Johanson, J., \& Vahlne, J. E. (2009). The Uppsala internationalization process model revisited: from liability of foreignness to liability of outsidership. Journal of International Business Studies, 40(9), 1411-1431.

Johanson, J., \& Wiedersheim-Paul, F. (1975). The internationalization of the firm: four Swedish cases 1. Journal of Management Studies, 12(3), 305-323.

Jones, M. V., Coviello, N., \& Tang, Y. K. (2011). International entrepreneurship research (1989-2009): a domain ontology and thematic analysis. Journal of Business Venturing, 26(6), 632-659.

Keupp, M. M., \& Gassmann, O. (2009). The past and the future of international entrepreneurship: a review and suggestions for developing the field. Journal of Management, 35(3), 600633.

Keupp, M. M., Palmié, M., \& Gassmann, O. (2012). The strategic management of innovation: a systematic review and paths for future research. International Journal of Management Reviews, 14(4), 367-390.

Khoo, C. S. G., Jin-Cheon, N., \& Jaidka, K. (2011). Analysis of the macro-level discourse structure of literature reviews. Online Information Review; Bradford, 35(2), 255-271. https://doi.org/10.1108/14684521111128032. 
Knowles, D., Mughan, T., \& Lloyd-Reason, L. (2006). Foreign language use among decision-makers of successfully internationalised SMEs: Questioning the language-training paradigm. Journal of Small Business and Enterprise Development, 13(4), 620-641.

Kogut, B., \& Zander, U. (1992). Knowledge of the firm, combinative capabilities, and the replication of technology. Organization Science, 3(3), 383-397.

Kraus, S., Harms, R., \& Fink, M. (2011). Family firm research: sketching a research field. International Journal of Entrepreneurship and Innovation Management, 13(1), 3247.

Krishnan, T. N., \& Scullion, H. (2017). Talent management and dynamic view of talent in small and medium enterprises. Human Resource Management Review, 27(3), 431-441.

Kuivalainen, O., Sundqvist, S., \& Servais, P. (2007). Firms' degree of born-globalness, international entrepreneurial orientation and export performance. Journal of World Business, 42(3), 253-267.

Leavy, B. (1994). The craft of case-based qualitative research. Irish Journal of Management, 15, 105.

Lebart, L., Morineau, A. and Warwick, K.M. (1984). Multivariate descriptive statistical analysis: correspondence analysis and related techniques for large matrices. New York: Wiley.

Lee, H., Kelley, D., Lee, J., \& Lee, S. (2012). SME survival: the impact of internationalization, technology resources, and alliances. Journal of Small Business Management, 50(1), 1-19.

Levitt, T., (1983). The globalization of markets [WWW Document]. Harvard Business Review. URL https://hbr. org/1983/05/the-globalization-of-markets. Accessed 11 March 2017

Liñán, F., \& Fayolle, A. (2015). A systematic literature review on entrepreneurial intentions: citation, thematic analyses, and research agenda. International Entrepreneurship and Management Journal, 11(4), 907-933.

Loane, S., \& Bell, J. (2006). Rapid internationalisation among entrepreneurial firms in Australia, Canada, Ireland and New Zealand: an extension to the network approach. International Marketing Review, 23(5), 467-485.

López-Duarte, C., González-Loureiro, M., Vidal-Suárez, M. M., \& González-Díaz, B. (2016). International strategic alliances and national culture: mapping the field and developing a research agenda. Journal of World Business, 51(4), 511-524.

Lu, J. W., \& Beamish, P. W. (2001). The internationalization and performance of SMEs. Strategic Management Journal, 22(6-7), 565-586.

Madsen, T. K., \& Servais, P. (1997). The internationalization of born globals: an evolutionary process? International Business Review, 6(6), 561-583.

Mangematin, V., Lemarié, S., Boissin, J. P., Catherine, D., Corolleur, F., Coronini, R., \& Trommetter, M. (2003). Development of SMEs and heterogeneity of trajectories: the case of biotechnology in France. Research Policy, 32(4), 621-638.

McDougall, P. P. (1989). International versus domestic entrepreneurship: new venture strategic behavior and industry structure. Journal of Business Venturing, 4(6), 387-400.

McDougall, P. P., \& Oviatt, B. M. (1996). New venture internationalization, strategic change, and performance: a follow-up study. Journal of Business Venturing, 11(1), 23-40.
McDougall, P. P., Shane, S., \& Oviatt, B. M. (1994). Explaining the formation of international new ventures: the limits of theories from international business research. Journal of Business Venturing, 9(6), 469-487.

McKelvey, B. (1997). Quasi-natural organization science. Organization Science, 8, 352-380.

Meyers, M. C., \& van Woerkom, M. (2013). Talent - Innate or acquired? Theoretical considerations and their implications for talent management. Human Resource Management Review, 23, 305-321.

Mole, K. (2002). Business advisers' impact on SMEs: an agency theory approach. International Small Business Journal, 20(2), 139-162.

Musteen, M., Datta, D. K., \& Butts, M. M. (2014). Do international networks and foreign market knowledge facilitate SME internationalization? Evidence from the Czech Republic. Entrepreneurship Theory and Practice, 38(4), 749-774.

Nolan, C. T., \& Garavan, T. N. (2016). Problematizing HRD in SMEs: a "critical" exploration of context, informality, and empirical realities. Human Resource Development Quarterly, 27(3), 407-442.

Nummela, N., Saarenketo, S., \& Puumalainen, K. (2004). A global mindset - a prerequisite for successful internationalization? Canadian Journal of Administrative Sciences/Revue Canadienne des Sciences de l'Administration, 21(1), 51-64.

O'Donnell, A., \& Cummins, D. (1999). The use of qualitative methods to research networking in SMEs. Qualitative Market Research: An International Journal, 2(2), 82-91.

O'Connell, P. K. (2014). A simplified framework for 21 st century leader development. The Leadership Quarterly, 25(2), 183203.

Ohmae, K. (1990). The borderless world. New York: Harper.

Oviatt, B. M., \& McDougall, P. P. (1994). Toward a theory of international new ventures. Journal of International Business Studies, 25(1), 45-64.

Oviatt, B. M., \& McDougall, P. P. (2005). Defining international entrepreneurship and modeling the speed of internationalization. Entrepreneurship Theory and Practice, 29(5), 537-554.

Pangarkar, N. (2008). Internationalization and performance of small-and medium-sized enterprises. Journal of World Business, 43(4), 475-485.

Piekkari, R., and Welch, C. (Eds.). (2011). Rethinking the case study in international business and management research. Cheltenham, UK: Edward Elgar.

Priem, R. L., \& Butler, J. E. (2001). Is the resource-based "view" a useful perspective for strategic management research? Academy of Management Review, 26(1), 22-40.

Ramamurti, R. (2012). What is really different about emerging market multi-nationals? Global Strategy Journal, 2, 41-47.

Ratten, V., Dana, L. P., Han, M., \& Welpe, I. (2007). Internationalisation of SMEs: European comparative studies. International Journal of Entrepreneurship and Small Business, 4(3), 361-379.

Reiche, B. S. (2012). Knowledge benefits of social capital upon repatriation: a longitudinal study of international assignees. Journal of Management Studies, 49(6), 1052-1077.

Rialp, A., Rialp, J., \& Knight, G. A. (2005). The phenomenon of early internationalizing firms: what do we know after a decade (1993-2003) of scientific inquiry? International Business Review, 14(2), 147-166. 
Ribau, C. P., Moreira, A. C., \& Raposo, M. (2018). SME internationalization research: mapping the state of the art. Canadian Journal of Administrative Sciences/Revue Canadienne des Sciences de l'Administration, 35(2), 280-303.

Ruzzier, M., Hisrich, R. D., \& Antoncic, B. (2006). SME internationalization research: past, present, and future. Journal of Small Business and Enterprise Development, 13(4), 476497.

Ruzzier, M., AntonciC, B., Hisrich, R. D., \& Konecnik, M. (2007). Human capital and SME internationalization: a structural equation modeling study. Canadian Journal of Administrative Sciences/Revue Canadienne des Sciences de l'Administration, 24(1), 15-29.

Saggese, S., Sarto, F., \& Cuccurullo, C. (2016). Evolution of the debate on control enhancing mechanisms: a systematic review and bibliometric analysis. International Journal of Management Reviews, 18(4), 417-439.

Sapienza, H. J., Autio, E., George, G., \& Zahra, S. A. (2006). A capabilities perspective on the effects of early internationalization on firm survival and growth. Academy of Management Review, 31(4), 914-933.

Senik, Z. C., Scott-Ladd, B., Entrekin, L., \& Adham, K. A. (2011). Networking and internationalization of SMEs in emerging economies. Journal of International Entrepreneurship, 9(4), 259-281.

Seuring, S., \& Gold, S. (2012). Conducting content-analysis based literature reviews in supply chain management. Supply Chain Management, 17(5), 544-555.

Shavelson, R. J., Town, L., \& National Research Council. (2002). Scientific research in education. Washington, D.C: National Academies Press.

Short, J. C., \& Palmer, T. B. (2008). The application of DICTION to content analysis research in strategic management. Organizational Research Methods, 11(4), 727-752.

Sinkovics, R. R., Kurt, Y., \& Sinkovics, N. (2018). The effect of matching on perceived export barriers and performance in an era of globalization discontents: empirical evidence from UK SMEs. International Business Review., 27(5), 1065-1079. https://doi.org/10.1016/j.ibusrev.2018.03.007.

Soto-Acosta, P., Colomo-Palacios, R., \& Popa, S. (2014). Web knowledge sharing and its effect on innovation: an empirical investigation in SMEs. Knowledge Management Research \& Practice, 12(1), 103-113.

Stoian, M. C., Dimitratos, P., \& Plakoyiannaki, E. (2018). SME internationalization beyond exporting: a knowledge-based perspective across managers and advisers. Journal of World Business, 53(5), 768-779.

Tatoglu, E., Bayraktar, E., Golgeci, I., Koh, S. L., Demirbag, M., \& Zaim, S. (2016). How do supply chain management and information systems practices influence operational performance? Evidence from emerging country SMEs. International Journal of Logistics Research and Applications, 19(3), 181-199.
Teece, D. J. (2007). Explicating dynamic capabilities: the nature and microfoundations of (sustainable) enterprise performance. Strategic Management Journal, 28(13), 1319-1350.

Terjesen, S., Hessels, J., \& Li, D. (2016a). Comparative international entrepreneurship: a review and research agenda. Journal of Management, 20(10), 1-46.

Terjesen, S., Hessels, J., \& Li, D. (2016b). Comparative international entrepreneurship: a review and research agenda. Journal of Management, 42(1), 299-344.

Thorpe, R., Holt, R., Macpherson, A., \& Pittaway, L. (2005). Using knowledge within small and medium-sized firms: a systematic review of the evidence. International Journal of Management Reviews, 7(4), 257-281.

Tranfield, D., Denyer, D., \& Smart, P. (2003). Towards a methodology for developing evidence-informed management knowledge by means of systematic review. British Journal of Management, 14(3), 207-222.

Valverde, M., Scullion, H., \& Ryan, G. (2013). Talent management in Spanish medium-sized organisations. The International Journal of Human Resource Management, 24(9), 1832-1852.

Van de Vrande, V., De Jong, J. P., Vanhaverbeke, W., \& De Rochemont, M. (2009). Open innovation in SMEs: trends, motives and management challenges. Technovation, 29(6), 423-437.

Welch, L. S., \& Luostarinen, R. (1988). Internationalization: evolution of a concept. Journal of General Management, 14(2), 34-55.

Welsh, D.H.B. \& Raven, P. (2006), Family business in the Middle east: An eexploratory study of retail management in Kuwait and Lebanon. Family Business Review, 19(1), 29-48.

Wernerfelt, B. (1984). A resource-based view of the firm. Strategic Management Journal, 5(2), 171-180.

Westwood, R., \& Linstead, S. (2001). Language/organisation: introduction. In R. Westwood \& S. Linstead (Eds.), The language of organization (pp. 1-19). London: Sage.

Wright, M., Westhead, P., \& Ucbasaran, D. (2007). Internationalization of small and medium-sized enterprises (SMEs) and international entrepreneurship: a critique and policy implications. Regional Studies, 41(7), 1013-1030.

Yamin, M., \& Kurt, Y. (2018). Revisiting the Uppsala internationalization model: social network theory and overcoming the liability of outsidership. International Marketing Review, 35(1), 2-17.

Young, S., Dimitratos, P., \& Dana, L.-P. (2003). International entrepreneurship research: what scope for international business theories. Journal of International Entrepreneurship, $1(1), 31-42$.

Publisher's note Springer Nature remains neutral with regard to jurisdictional claims in published maps and institutional affiliations. 